\title{
Significant Improvements in the Performance of an Established Affinity Chromatography Procedure Employed to Purify a Monoclonal Antibody in 100 Purification Cycles
}

\author{
Williams Ferro ${ }^{1}$, Rodolfo Valdés ${ }^{1 *}$, Eutimio Fernández ${ }^{2}$, Yarysel Guevara ${ }^{1}$, Yenisley Medina ${ }^{1}$, Tatiana Álvarez ${ }^{1}$, Andrés Tamayo ${ }^{1}$, Tatiana $^{2}$
} González $^{3}$, Mayra Wood ${ }^{3}$, Maylín La O4, Yodelvis Calvo ${ }^{4}$ and Déborah Geada

${ }^{1}$ Monoclonal Antibody Department, Center for Genetic Engineering and Biotechnology, Ave 31/ 158 and 190, P.O. Box 6162, Havana 10600, Cuba ${ }^{2}$ Nuclear and Energy Research Institute, Ave. Lineu Prestes, 2242, Cidade Universitaria, Butantã, Sao Paulo, 05508000, Brazil

${ }^{3}$ Process Control Department, Center for Genetic Engineering and Biotechnology, Ave 31/ 158 and 190, P.O. Box 6162, Havana 10600, Cuba

${ }^{4}$ Quality Control Department, Center for Genetic Engineering and Biotechnology, Ave 31/ 158 and 190, P.O. Box 6162, Havana 10600, Cuba

${ }^{5}$ Tobacco Research Institute, San Antonio de los Baños, Havana 3500, Cuba

\begin{abstract}
Protein A-Sepharose affinity chromatography is a very successful method for the purification of immunoglobulins for pharmaceutical use. However, the chromatography efficiency and lifetime of this method have to be always adjusted to specific chromatography conditions (biological source, buffers, flow rates, antibody properties, temperature, protein concentration, cleaning protocol, etc). This study sought to demonstrate improvements in the performance of an established affinity chromatography procedure employed to purify the CB.Hep-1 monoclonal antibody (mAb) used in the purification of the active pharmaceutical ingredient of a Hepatitis B vaccine. In conclusion, the relative poor mAb recovery observed in $150 \mathrm{mM}$ PBS; $\mathrm{pH}$ 8.0/100 mM citric acid; $\mathrm{pH} 3.0$ buffer system conditions was attributed to the inefficacy of the elution buffer to disrupt completely interactions between the matrix and $\mathrm{mAb}$. In this regard, retention of the CB.Hep-1 mAb into the matrix was helped by the ligand coupled to the matrix and not by unspecific interactions. The $1.5 \mathrm{M}$ glycine- $\mathrm{NaOH} / 3 \mathrm{M} \mathrm{NaCl} ; \mathrm{pH} 9.0 / 200 \mathrm{mM}$ glycine-HCl; $\mathrm{pH} 2.5$ buffer system significantly improved the affinity chromatography recovery without affecting mAb purity, molecular homogeneity, ligand leakage and mouse DNA content in 100 purification cycles. Thus, application of $1.5 \mathrm{M}$ glycine- $\mathrm{NaOH} / 3 \mathrm{M} \mathrm{NaCl}$; $\mathrm{pH}$ 9.0/200 mM glycine-HCl; pH 2.5 as buffer system allowed the reduction of the CB.Hep-1 mAb and Hepatitis B vaccine costs, respectively.
\end{abstract}

Keywords: Affinity chromatography; CB.Hep-1 monoclonal antibody; Protein A-Sepharose

\section{Introduction}

Monoclonal antibodies $(\mathrm{mAb})$ play an important role in therapy, immunodiagnostic and purification of molecules by immunoaffinity chromatography $[1,2]$. Bottlenecks of mAb manufacturing processes currently have moved to downstream processes; thus purification costs are now outbalancing upstream costs as a consequence of fermentation capacity increase protein expression level of the cell lines [3,4].

Generally, the platform of mAb downstream processes includes particle removal by centrifugation or filtration followed by an affinity chromatography and some viral inactivation steps [5]. The most important step of this platform is the affinity chromatography, because of its high selectivity, which leads to a very high $\mathrm{mAb}$ purity. Within affinity chromatography techniques used to purify mAb staphylococcal Protein A-Sepharose affinity chromatography is perhaps the most widely applied. It is a very robust and universal platform to purify almost any kind of immunoglobulins from a diverse range of starting biological sources. Nevertheless, this matrix is usually a significant component of the whole purification cost with respect to other properties. Therefore, an optimal usage of expensive Protein A-Sepharose affinity chromatography matrices would significantly reduce purification process cost. In this sense, there are several parameters, which can affect the yield, purity of eluted $\mathrm{mAb}$ and Protein A-affinity chromatography matrices lifetime; and consequently the cost of the purification process. Within them, adsorption and elution buffers play a significant role $[6,7]$.
On the other hand, the decreasing trend in prices of the Hepatitis B vaccines, due to a declining incidence of this disease as a consequence of a successfully worldwide vaccination program makes mandatory improvements in the CB.Hep-1 mAb [8], downstream process to increase the recovery and thus reduce the $\mathrm{mAb}$ and vaccine production cost.

For that reason, the subjects of the present research were (I) to detect principal drawbacks in an established Protein A-Sepharose Fast Flow (PASFF) affinity chromatography used at industrial scale to purify the CB.Hep-1 mAb, which employs a phosphate/citric acid buffer system and (II) to test a new buffer system to demonstrate significant improvements in the CB.Hep- $1 \mathrm{mAb}$ recovery in 100 purification cycles for reducing the $\mathrm{mAb}$ and vaccine purification process cost, respectively.

*Corresponding author: Rodolfo Valdés Véliz, PhD, Monoclonal Antibody Department, Center for Genetic Engineering and Biotechnology. Ave 31/ 158 and 190, P.O. Box 6162, Havana 10600, Cuba, Tel: +2504469; Fax: +2714764; E-mail: rodolfo.valdes@cigb.edu.cu

Received October 29, 2011; Accepted November 19, 2011; Published Novembe 21, 2011

Citation: Ferro W, Valdés R, Fernández E, Guevara Y, Medina Y, et al. (2011) Significant Improvements in the Performance of an Established Affinity Chromatography Procedure Employed to Purify a Monoclonal Antibody in 100 Purification Cycles. Pharm Anal Acta 2:143. doi:10.4172/2153-2435.1000143

Copyright: ( 2011 Ferro W, et al. This is an open-access article distributed unde the terms of the Creative Commons Attribution License, which permits unrestricted use, distribution, and reproduction in any medium, provided the original author and source are credited. 
Citation: Ferro W, Valdés R, Fernández E, Guevara Y, Medina Y, et al. (2011) Significant Improvements in the Performance of an Established Affinity Chromatography Procedure Employed to Purify a Monoclonal Antibody in 100 Purification Cycles. Pharm Anal Acta 2:143. doi:10.4172/21532435.1000143

Page 2 of 6

\section{Materials and Methods}

\section{Chromatography matrices}

PASFF, Sepharose 4 Fast Flow and Sephadex G-25 were from Amersham-Biosciencies (Uppsala Sweden).

Loading study of the CB.Hep-1 mAb using the established PASFF affinity chromatography procedure

Ascites contained the CB.Hep-1 mAb (30 mg) was applied to each PD-10 column (Amersham-Biosciences, Uppsala, Sweden) packed with $2 \mathrm{~mL}$ of PASFF using both buffer systems (I, $150 \mathrm{mM}$ M PBS; $\mathrm{pH}$ 8.0/100 mM citric acid; $\mathrm{pH} 3.0$ and II, $1.5 \mathrm{M}$ glycine- $\mathrm{NaOH} / 3 \mathrm{M}$ $\mathrm{NaCl} ; \mathrm{pH}$ 9.0/200 mM glycine-HCl; $\mathrm{pH} 2.5$ ). All eluted fractions were neutralized with $2 \mathrm{M}$ Tris to allow buffer exchange to $20 \mathrm{mM}$ Tris/150 $\mathrm{mM} \mathrm{NaCl}$; $\mathrm{pH} 7.6$ by gel filtration chromatography in Sephadex G-25 and protein characterization. Affinity columns were operated at 48 $\mathrm{cm} / \mathrm{h}$ and the concentration of $\mathrm{mAb}$ applied to the columns was always $15 \mathrm{mg} / \mathrm{mL}$.

\section{Regeneration and in-situ cleaning of PASFF matrix}

The PASFF column was regenerated after each purification cycle with $100 \mathrm{mM}$ citric acid; $\mathrm{pH} 3$ and the in-situ cleaning was performed after each purification cycle with five times column volume of $70 \%$ ethanol (Merck) at $1 \mathrm{~mL} / \mathrm{min}$.

\section{Quantification of proteins}

Proteins were quantified by the procedure described by Lowry using Bovine serum albumin (BSA) as standard [9]. Calibration curve ranged $100-500 \mu \mathrm{g} / \mathrm{mL}$ and sample absorbance was measured at 730 $\mathrm{nm}$ in a UV-Visible Ultrospec 2000 Spectrophotometer (Pharmacia Biotech, Cambridge, UK).

\section{Estimation of the CB.Hep-1 mAb Concentration by Enzyme-} Linked Immunosorbent Assay (ELISA)

A validated ELISA was employed to estimate mAb concentration. Detection of antigen-antibody reaction was achieved using an antimouse IgG horseradish peroxidase conjugated, revealing the enzyme activity with o-phenylenediamine (OPD) (Sigma, St Louis, USA) substrate. Reaction was stopped with $2.5 \mathrm{M} \mathrm{H}_{2} \mathrm{SO}_{4}$ and absorbance was measured at $492 \mathrm{~nm}$ using a Multiskan ELISA reader (Labsystem, Helsinki, Finland) [10].

\section{Detection of the CB.Hep-1 mAb Retained in the PASFF by SDS-PAGE}

Samples $(20 \mu \mathrm{g})$ of the previously purified CB.Hep-1 mAb were analyzed under reducing conditions by electrophoresis on $12.5 \%$ SDSPAGE [11]. Bands of proteins were stained with Coomassie blue R-250 (Bio-Rad, California, USA). The purity was analyzed by densitometry using the Molecular Analyst, version 1.4.1 software. Before sample application in SDS-PAGE, PASFF $(0.1 \mathrm{~g})$ was heated at $100^{\circ} \mathrm{C}$ under reducing conditions for $5 \mathrm{~min}$. The sepharose $4 \mathrm{FF}$, without Protein $\mathrm{A}$, used in only one the CB.Hep-1 mAb purification cycle served as negative control.

\section{Estimation of the mouse DNA content by hybridization method}

A sample volume containing $1 \mathrm{mg}$ of $\mathrm{mAb}$ was mixed with $1 \mathrm{~mL}$ of phenol. Then, a centrifugation at $1300 \mathrm{~g}$ for $15 \mathrm{~min}$ was done. Top phase was blended with similar phenol/chloroform volume (v/v) and centrifuged 140 at $1300 \mathrm{xg}$ for $15 \mathrm{~min}$. Supernatant was mixed with 2-butanol (v/v) and centrifuged again, top phase was discarded. In parallel, different dilutions of mouse chromosomal DNA (1 ng-3.9 pg) were prepared. The BSA $(100 \mu \mathrm{g})$ free of DNA was used as negative control. The technique quantification limit was $7.5 \mathrm{pg} / \mathrm{mg}$ of protein [12].

\section{Estimation of the CB.Hep-1 mAb purity by SDS-PAGE in the lifetime study}

Samples $(20 \mu \mathrm{g})$ of the purified CB.Hep-1 mAb were analyzed under reducing conditions by electrophoresis on $12.5 \%$ SDS-PAGE [11]. Bands of proteins were stained with Coomassie blue R-250 (BioRad, California, USA). Samples were analyzed from purification cycles $1,10,30,60,100$, respectively.

Estimation of the CB.hep-1 mAb purity and molecular homogeneity in the lifetime study

The molecular distribution and purity of the CB.Hep-1 mAb were also estimated by using a HPLC-GF column TSK G3000 PW (600 $\mathrm{mm} / 57.5 \mathrm{~mm}$ I.D., TosoHaas, Japan). The chromatographic mobile phase employed was $150 \mathrm{mM}$ PBS; pH 7.0 and $100 \mu \mathrm{g}$ of the samples dissolved in $150 \mathrm{mM}$ PBS; $\mathrm{pH} 7.0$ were directly applied into the system. The volumetric flow rate employed was $200 \mu \mathrm{L} / \mathrm{min}$ and absorbance was measured at $226 \mathrm{~nm}$. Samples were analyzed from purification cycles $1,10,30,60,100$, respectively.

\section{Estimation of the protein a concentration by ELISA}

A high binding plate (COSTAR, USA) was coated with $10 \mu \mathrm{g} /$ $\mathrm{mL}$ of specific sheep polyclonal antibodies against Protein A (SpAc1). Concentrations of standard Protein A ranged 0.19-3.13 ng/mL previously diluted in $0.5 \%$ skim milk/0.15 M PBS/0.1\% Tween 20 ; $\mathrm{pH}$ 7.2. Standard and samples were boiled for $3 \mathrm{~min}$ and centrifuged at $10000 \mathrm{xg}$ in a Universal 16 centrifuge, (Hettich, Germany). Then, both were applied to the plate and incubated for $2 \mathrm{~h}$ at $37^{\circ} \mathrm{C}$. Reaction between SpAc1 and Protein A was detected through the SpAc1peroxidase conjugate. Reaction was revealed adding $0.015 \% \mathrm{H}_{2} \mathrm{O}_{2}$ and OPD (Sigma, St Louis, USA) and stopped with $2.5 \mathrm{M} \mathrm{H}_{2} \mathrm{SO}_{4}$. Absorbance was measured at $492 \mathrm{~nm}$ using a Multiskan ELISA reader (Labsystem, Helsinki, Finland) [13].

\section{Estimation of the CB.hep-1 mAb "Specific Activity"}

The antibody specific activity was calculated as the ratio between the CB.Hep-1 mAb concentration measured by ELISA [10] and total protein concentration measured by the Lowry method [9].

\section{Preliminary proof-of - concept studies}

Preliminary study I. A PD-10 column (Amersham-Biosciences, Uppsala, Sweden) packed with $2 \mathrm{~mL}$ of PASFF was loaded with the purified CB.Hep-1 mAb $(15.2 \mathrm{mg} / \mathrm{mL})$ using a buffer system based on $1.5 \mathrm{M}$ glycine- $\mathrm{NaOH} / 3 \mathrm{M} \mathrm{NaCl} ; \mathrm{pH} 9.0 / 200 \mathrm{mM}$ glycine- $\mathrm{HCl} ; \mathrm{pH}$ 2.5.The eluted fractions were also neutralized with $2 \mathrm{M}$ Tris to allow buffer exchange to $20 \mathrm{mM}$ Tris/ $150 \mathrm{mM} \mathrm{NaCl}$; $\mathrm{pH} 7.6$ by gel filtration chromatography in Sephadex G-25. The affinity column was operated at $48 \mathrm{~cm} / \mathrm{h}$.

Preliminary study II. Ascites (12 mL) contained the CB.Hep-1 $\mathrm{mAb}$ was applied to each PD-10 column (Amersham-Biosciences, Uppsala, Sweden) packed with $2 \mathrm{~mL}$ of PASFF using both buffer systems (I. $150 \mathrm{mM}$ M PBS; pH 8.0/100 mM citric acid; pH 3.0 and II, $1.5 \mathrm{M}$ glycine- $\mathrm{NaOH} / 3 \mathrm{M} \mathrm{NaCl} ; \mathrm{pH} 9.0 / 200 \mathrm{mM}$ glycine- $\mathrm{HCl}$; 
Citation: Ferro W, Valdés R, Fernández E, Guevara Y, Medina Y, et al. (2011) Significant Improvements in the Performance of an Established Affinity Chromatography Procedure Employed to Purify a Monoclonal Antibody in 100 Purification Cycles. Pharm Anal Acta 2:143. doi:10.4172/21532435.1000143

Page 3 of 6

$\mathrm{pH}$ 2.5). All eluted fractions were neutralized with $2 \mathrm{M}$ Tris to allow buffer exchange to $20 \mathrm{mM}$ Tris/150 mM NaCl; $\mathrm{pH} 7.6$ by gel filtration chromatography in Sephadex G-25 and protein characterization. Both affinity columns were operated at $48 \mathrm{~cm} / \mathrm{h}$. Concentration of $\mathrm{mAb}$ applied to the columns was always $16.4 \mathrm{mg} / \mathrm{mL}$. Regeneration of the Protein A-Sepharose FF matrix was done after each purification cycle with $100 \mathrm{mM}$ citric acid; $\mathrm{pH}$, while the in-situ cleaning of the Protein A-Sepharose column was performed after each purification cycle but with five time column volume of $70 \%$ ethanol (Merck) at $1 \mathrm{~mL} / \mathrm{min}$. This experiment was done in triplicate.

\section{Lifetime study}

Each PD-10 column (Amersham-Biosciences, Uppsala, Sweden) packed with $2 \mathrm{~mL}$ of PASFF were loaded with ascites $(12 \mathrm{~mL})$ contained the CB.Hep-1 mAb (load $15.5 \mathrm{mg} / \mathrm{mL}$ of matriz) using both buffer systems (I, $150 \mathrm{mM}$ M PBS; pH 8.0/100 mM citric acid; $\mathrm{pH} 3.0$ and II, $1.5 \mathrm{M}$ glycine- $\mathrm{NaOH} / 3 \mathrm{M} \mathrm{NaCl}$; $\mathrm{pH} 9.0 / 200 \mathrm{mM}$ glycine- $\mathrm{HCl}$; $\mathrm{pH}$ 2.5). Elution fractions were also neutralized with $2 \mathrm{M}$ Tris to allow buffer exchange to $20 \mathrm{mM}$ Tris/ $150 \mathrm{mM} \mathrm{NaCl}$; $\mathrm{pH} 7.6$ by gel filtration chromatography in Sephadex G-25. Both assessed affinity columns were operated at $48 \mathrm{~cm} / \mathrm{h}$. This procedure was repeated 100 purification cycles. The protocols used for regeneration and in-situ cleaning of the PASFF matrix were similar to those describe above.

\section{Statistical analysis}

Statgraphics Plus version 5.0 (2000) from Statistical Graphics, Design Expert version 6.0.1 and Microsoft Excel softwares were used in this study. One factor experimental design with 5 levels was performed to study the load influence; four repetitions were carried out in each level. A student t's test with $\alpha=0.05$ was used to compare chromatographic parameters among assessed buffer systems in the preliminary study. Adsorption and elution capacity were also statistically analyzed by the Mann and Whitney W test in the lifetime study.

\section{Results and Discussion}

The purification of $\mathrm{mAb}$ used for vaccine production with low aggregated values needs the design of very efficient downstream processes to reduce vaccine cost. In order to improve an industrial scale CB.Hep-1 mAb purification protocol based on the PASFF affinity chromatography, two buffer systems were assessed in repetitive 100 purification cycles at analytical scale. To start this study, matrix adsorption capacity, matrix elution capacity and recovery of $\mathrm{mAb}$ were assessed as a function of the applied amount of the CB.Hep- $1 \mathrm{mAb}(10$, 15, 20, 25 and 30; (mg/mL of matrix)). In this sense, the best statistical models for each chromatographic parameter were illustrated in Figure $1 \mathrm{~A}$.

Adsorption capacity increased from 9.7 to $14.1 \mathrm{mg} \mathrm{mAb} / \mathrm{mL}$ of matrix within the assessed range of the applied amount of $\mathrm{mAb}$. While the elution capacity maintained statistically invariable $(8.4 \mathrm{mg} \mathrm{mAb} /$ $\mathrm{mL}$ of matrix). Difference between adsorption and elution capacity could be explained by inefficiency in the elution procedure based on $10 \mathrm{mM}$ citric acid; $\mathrm{pH} 3$ buffer. It is well known that responsiveness of the Protein A to $\mathrm{pH}$ is a function of hydrophobicity. At low $\mathrm{pH}$, the hystidyl residues, highly conserved residues, in the Protein A-binding site of IgG are fully charged minimally hydrophobic and mutually

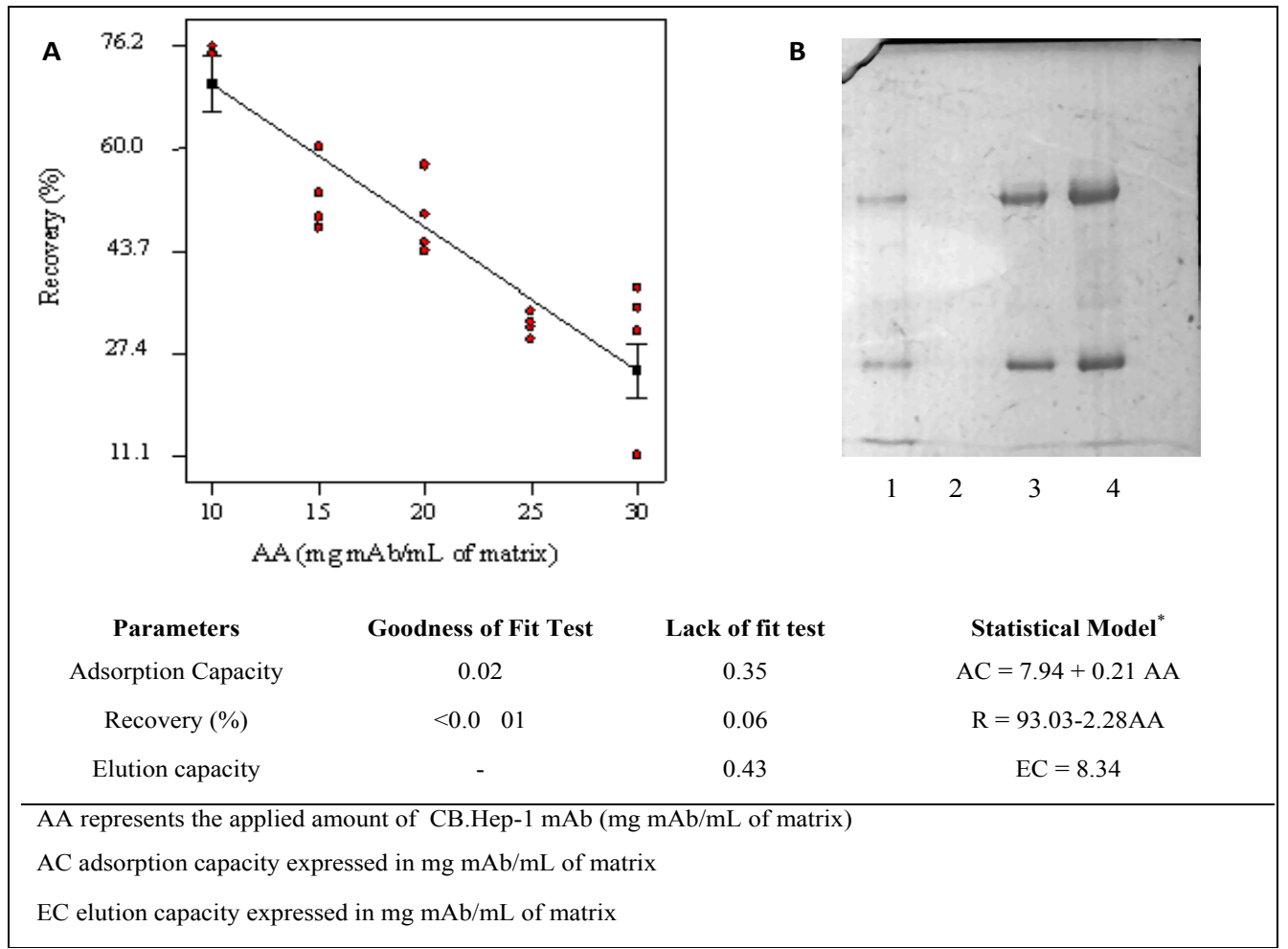

Figure 1: (A) Recovery plot for different applied amounts (AA) of the CB.Hep-1 mAb (phosphate/citric acid buffer system). (B) SDS-PAGE to demonstrate retention of the CB.Hep-1 mAb into the PASFF. Line 1, CB.Hep-1 mAb released from the PASFF after elution step. Line 2, CB.Hep-1 mAb released from the Sepharose 4 FF with

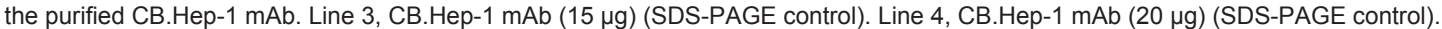


Citation: Ferro W, Valdés R, Fernández E, Guevara Y, Medina Y, et al. (2011) Significant Improvements in the Performance of an Established Affinity Chromatography Procedure Employed to Purify a Monoclonal Antibody in 100 Purification Cycles. Pharm Anal Acta 2:143. doi:10.4172/21532435.1000143

repellent [14]. Perhaps, this elution buffer was unable to charge fully of the hystidyl residues. As consequence, the mAb recovery decreased by $47.8 \%$ through studied interval of applied amount of mAb. Even the highest recovery ( $73.9 \%$ at $10 \mathrm{mg} \mathrm{mAb} / \mathrm{mL}$ of matrix) observed in this study would not be suitable for Protein A-Sepharose FF affinity chromatography because the recovery of this chromatography usually ranged $80-90 \%$ [14].

Due to the ELISA applied to the samples of the unbound fractions did not revealed presence of the CB.Hep- $1 \mathrm{mAb}$, we hypothesize that about $30 \%$ of the CB.Hep- $1 \mathrm{mAb}$ was retained into the affinity chromatography matrix. To confirm the CB.Hep- $1 \mathrm{mAb}$ retention into the PASFF, a SDS-PAGE experiment using this matrix after elution step was done (Figure 1B). As results, retention of $\mathrm{mAb}$ was confirmed when heavy and light chains of IgG were detected in heated PASFF after the elution step. Similar results were noted by us when the purification of the antigen was performed by immunoaffinity chromatography (data no shown).

To discard unspecific interactions of the CB.Hep-1 mAb with the PASFF, a size-exclusion chromatography using the same inert matrix but without the ligand (Protein A) was carried out. In this case, no IgG bands were observed in SDS-PAGE analysis, which did not reveal unspecific retention of $\mathrm{mAb}$ into the matrix. Therefore, retention of the CB.Hep- $1 \mathrm{mAb}$ into the matrix was helped by specific interactions with the Protein A.

Taken into consideration the relative poor recovery $(52.3 \pm 5.7 \%)$ caused by the reduced adsorption capacity and elution capacity manifested when phosphate/citric acid buffer system was used; both, adsorption and elution buffers were redefined. The new adsorption buffer assessed was $1.5 \mathrm{M}$ glycine- $\mathrm{NaOH} / 3 \mathrm{M} \mathrm{NaCl}$; $\mathrm{pH}$ 9, which has been recommended for this purpose because it enhances IgG binding capacity of Protein A [14]. However, sometimes it is not recommended for large scale $\mathrm{mAb}$ purification because adsorption improvements are not always justified in comparison with the cost increase. Regarding to this, sometimes glycine has same effectivity as other compounds such as sodium sulphate, polyethylene glycol (PEG), sodium chloride, ammonium sulphate and potassium phosphate. However, we choose glycine because this $\mathrm{mAb}$ is quite stable in glycine and it does not have PEG disadvantages in terms of viscosity and of ammonium sulphate, which is volatile creating instability in buffer $\mathrm{pH}$, toxicity and protein denaturalization.

Results of a preliminary proof-of-concept experiment applying the previously purified CB.Hep- $1 \mathrm{mAb}$ and the glycine buffer system to the affinity matrix showed an increase by $67 \%$ in the adsorption capacity $\left(P=1 \times 10^{-4}\right)$ and consequently in productivity, when $15 \mathrm{mg}$ of $\mathrm{mAb} /$ $\mathrm{mL}$ of matrix was applied (data no shown). The adsorption capacity enhancement detected in the PASFF could be explained by the high molar concentration of buffer because of the majority of binding energy comes from hydrophobic interactions. Similar results were observed in the elution capacity analysis $\left(P=3 \times 10^{-5}\right)$ and recovery $\left(P=2.5 \times 10^{-5}\right)$. Summarizing, recovery increased up to $96 \%$, which corroborated results reported by other authors [14]

After the first preliminary proof-of concept experiment using the previously purified CB.Hep-1 $\mathrm{mAb}$, another preliminary experiment using the CB.Hep-1 mAb and glycine buffer system but with ascitic fluid, a complex biological source was performed. In this demonstration, the recovery observed with phosphate/citric acid buffer system (control) was $52.3 \pm 5.7 \%$, whereas $96.0 \pm 1.9 \%$ was detected in the case of buffer system based on glycine $\left(P=2.4 \times 10^{-5}\right)$. Therefore, the use of glycine buffer system increased the CB.Hep-1 mAb recovery by 1.4 fold in this assessment (Table 1). In this case, both parameters (adsorption (9.0 $\pm 1.0-15.0 \pm 0.2$ and elution 7.8 $\pm 0.8-14.5 \pm 0.2$ ) showed significant improvements.

The mAb purity measured by SDS-PAGE and HPLC-GF showed no differences between the CB.Hep-1 mAb purified using both buffer systems (Table 1). Bands of 50-55 kDa and $25 \mathrm{kDa}$ representing classical profile of heavy and light chains of IgG were observed and evidences of $\mathrm{mAb}$ fragmentation were not detected. The new buffer system also improved substantially purification yield $(2.3 \mathrm{mg} \mathrm{mAb} / \mathrm{mL}$ of ascites) with respect to phosphate/citric acid buffer system $(1.6 \mathrm{mg} \mathrm{mAb} / \mathrm{mL}$ of ascites).

Several toxic effects such as alteration of the tissue uptake of immunocomplex, and toxic shock syndrome are associated with the presence of the staphylococcal Protein A [14]. In these mAb CB.Hep-1 elution fractions, the Protein A leakage was determined by an specific ELISA validated in presence of mouse inmunoblobulins, which permitted quantification without non-specific reactions the content of Protein A in mAb samples [13]. The content of this contaminant was less than $10 \mathrm{ppm}$ for all CB.Hep-1 samples (Table 1). It represents a very low amount of Protein A because other authors have reported values of Protein A leakage up to $64 \mathrm{ppm}$ using ELISA in ng range of sensitivity [15-17]. This might be explained by the fact that the interaction between Protein $\mathrm{A}$ and $\mathrm{IgG}_{2 b k}$ is not to high as to provoke a relative high release of the covalently-linked Protein A from the sorbent.

Due to the malignant transformation properties of the mammalian cellular DNA, the quantification of mouse DNA content in the mAb preparation is another point to consider. In such sense, regulatory agencies are very strict. Nowadays, the acceptable level ranged 100 pg-10 ng of residual cellular DNA per human dose [18]. The dot-blot analysis performed to estimate the mouse DNA content in the $\mathrm{mAb}$ CB.Hep-1 samples evidenced the high purification capacity of this chromatography because the mouse DNA presented in the purified $\mathrm{mAb}$ CB.Hep-1 did not exceed $7.5 \mathrm{pg} / \mathrm{mg}$ of IgG (Table 1 ). These values did not exhibited significant differences between both experimental conditions.

\begin{tabular}{|l|c|c|}
\hline Parameters & A & B \\
\hline Adsorption capacity (mg/mL of matrix) & $9.0 \pm 1.0$ & $15.0 \pm 0.2$ \\
\hline Adsorption capacity (\%) & $67.8 \pm 2.7$ & $98.7 \pm 8.3$ \\
\hline Elution capacity (mg/mL of matrix) & $7.8 \pm 0.8$ & $14.5 \pm 0.2$ \\
\hline Elution capacity (\%) & $86.6 \pm 0.3$ & $96.6 \pm 0.4$ \\
\hline Recovery (\%) & $52.3 \pm 5.7$ & $96.0 \pm 1.9$ \\
\hline Purity measured by SDS-PAGE (\%) & $99.2 \pm 1.0$ & $99.6 \pm 0.5$ \\
\hline Purity measured by size-exclusion-HPLC (\%) & $96.5 \pm 0.8$ & $97.0 \pm 2.82$ \\
\hline Mouse DNA content (mAb pg/mg total protein) & $<7.5$ & $<7.5$ \\
\hline Specific activity of purified CB.Hep-1 mAb (\%) & $98.3 \pm 22.1$ & $97.9 \pm 10.2$ \\
\hline mAb concentration (mg/mL) & $5.6 \pm 0.7$ & $3.3 \pm 0.6$ \\
\hline Protein A concentration (ng/mL) & $16.4 \pm 1.2$ & $4.2 \pm 1.7$ \\
\hline Protein A content (ppm) & $2.9 \pm 1.7$ & $1.2 \pm 1.2$ \\
\hline Buffer system cost (\$/g of purified mAb) & 1.0 & 4.4 \\
\hline Productivity (mg mAb/L of matrix per hour) & 50.9 & 96.1 \\
\hline Productivity increase (\%) & 100.0 & 188.6 \\
\hline
\end{tabular}

Table 1: Results of the preliminary experiment II to purify the CB.Hep-1 mAb using ascites as complex biological source and both buffer systems $(n=3)$. Buffer System A: 150 mM PBS, pH 8.0/100 mM citric acid, pH 3.0. Buffer System B: 500 $\mathrm{mM}$ glycine- $\mathrm{NaOH} / 3 \mathrm{M} \mathrm{NaCl}$, pH 9.0/200 mM glycine- $\mathrm{HCl}$, pH 2.5 . 
Citation: Ferro W, Valdés R, Fernández E, Guevara Y, Medina Y, et al. (2011) Significant Improvements in the Performance of an Established Affinity Chromatography Procedure Employed to Purify a Monoclonal Antibody in 100 Purification Cycles. Pharm Anal Acta 2:143. doi:10.4172/21532435.1000143

Page 5 of 6

It is usual that matrix manufactures recommend the use of $\mathrm{pH}$ values in the elution buffer lower than 3 (1.5-2) to increase the elution capacity of matrixes, although these $\mathrm{pH}$ conditions would considerably affect the antigen binding capacity of $\mathrm{mAb}$. In this study, the influence of the $\mathrm{pH}$ value 2.5 on the antigen recognition capacity of the CB.Hep-1 $\mathrm{mAb}$ was indirectly measured by the determination of the $\mathrm{mAb}$ "specific activity". Results demonstrated that this $\mathrm{pH}$ condition did not modify the HBsAg recognition capacity of the CB.Hep-1 mAb (Table 1).

Finally, the stability of the PASFF purifying the CB.Hep-1 mAb with the glycine buffer system was assessed in 100 purification cycles using ascites rich in the CB.Hep-1 mAb. The affinity chromatography columns were loaded at a capacity equivalent to $15 \mathrm{mg} \mathrm{IgG} / \mathrm{mL}$ of matrix in every purification cycle and $\mathrm{mAb}$ were then harvested in one elution fraction as indicated above. Figure 2 illustrates an overlapping representation of representative chromatograms (purification cycles 1 , $10,30,69$ and 100) registered in the lifetime study. As it can be seen individual chromatograms were almost distinguishable in both buffer conditions demonstrating the high repeatability or consistence of the improved procedure.

The recovery trend of the CB.Hep-1 mAb was illustrated in the Figure 3. This study resulted in an average $m A b$ recovery $=29.4 \pm 19.79 \%$ for phosphate/citric acid buffer system and $47.18 \pm 26.67 \%$ for glycine buffer system $\left(P=1.9 \times 10^{-5}\right)$, which allow to corroborate results of the preliminary experiments but in 100 purification cycles. Again statistical differences were detected in the adsorption $\left(P=1.94 \times 10^{-11}\right)$ and elution capacity $\left(P=8.79 \times 10^{-5}\right)$ between both experimental conditions.

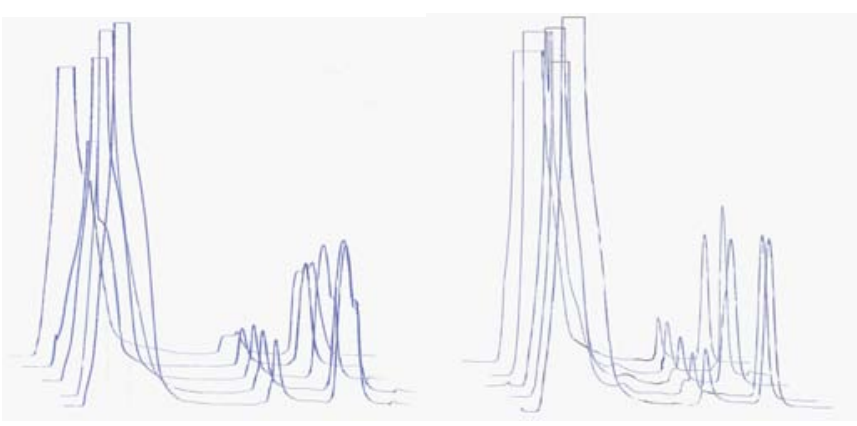

Figure 2: Partial overlay of the elution profiles of representative purification cycles $(1,10,30,60$ and 100) of the life time study. (Left) $150 \mathrm{mM} \mathrm{PBS,} \mathrm{pH}$ $8.0 / 100 \mathrm{mM}$ citric acid, pH 3.0 buffer system. (Right). 1.5M glycine-NaOH/3M $\mathrm{NaCl} ; \mathrm{pH}$ 9.0/200 mM glycine-HCl; pH 2.5.

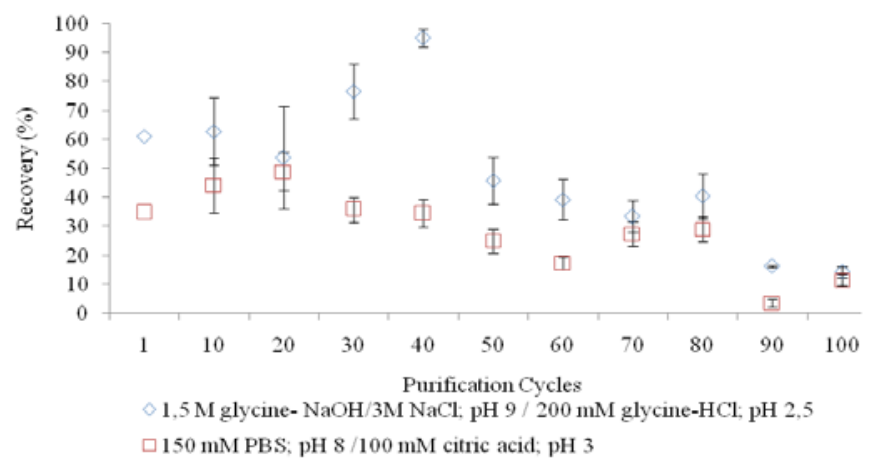

Figure 3: Results of the CB.Hep-1 mAb recovery in the PASFF affinity chromatography of the life time study.

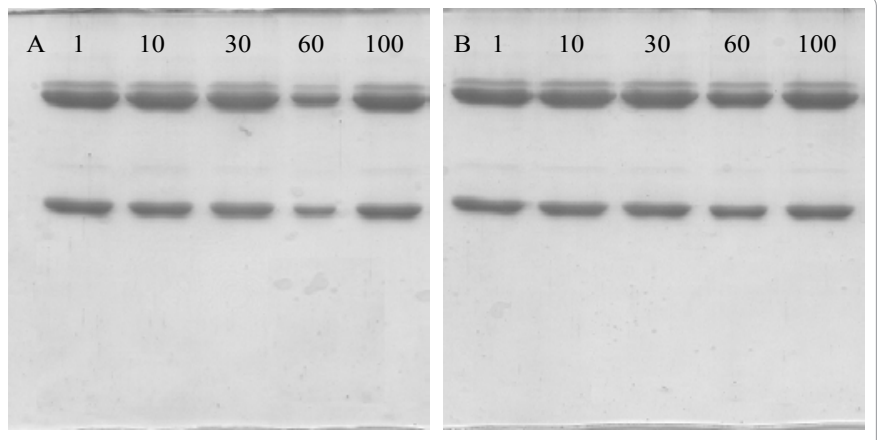

Figure 4: Results of the SDS-PAGE analysis to measure the purity of the CB.Hep-1 mAb purified by the PASFF affinity chromatography in the lifetime study (purification cycles: (1, 10, 30, 60 and 100). (Left) $150 \mathrm{mM}$ PBS; pH 8.0/100 mM citric acid; pH 3.0 buffer system. (Right) $1.5 \mathrm{M}$ glycine- $\mathrm{NaOH} / 3 \mathrm{M}$ $\mathrm{NaCl}$; pH 9.0/200 mM glycine-HCl; pH 2.5 buffer system.

The antibody SDS-PAGE profiles obtained under reducing conditions (Figure 4) reveals no substantial differences among the purity measured in samples of the different purification cycles. Bands of approximately $50-55 \mathrm{kDa}$ and $25 \mathrm{kDa}$ represent the typical profile of the heavy and light chains of IgG. These profiles showed no evidence of fragmentation in the CB.Hep-1 molecule during the whole life time study. Results of the analysis of the purity and molecular homogeneity of the CB.Hep-1 performed by HPLC-GF did not evidenced differences in this parameter in samples of the $\mathrm{mAb}$ purified using both purification buffer systems (Figure 5). The second small fraction observed corresponded always with residues of the acid PASFF elution buffer and nit with fragment of the proteins. Thus, the number of the purification cycles had no significant effect on the purity of $\mathrm{mAb}$ CB.Hep-1.

Summarizing, taking into account the application of this $\mathrm{mAb}$ in vaccine manufacturing, our findings ( $\mathrm{mAb}$ yield and process productivity increase) would make possible the purification $40 \%$ approximately more Hepatitis B surface antigen and consequently of vaccine doses using the same starting biological source volume for $\mathrm{mAb}$ purification. Beside the positive economical impact provoked by this vaccine production increase, the decrease in the CB.Hep-1 mAb unitary cost would additionally decrease drastically vaccine production cost. Therefore, $\mathrm{mAb}$ purification cost increase by glycine buffer system price (four-fold) is not significant with respect to benefits of its application, which is contradiction with previous reports [14].

\section{Conclusions}

The relative poor $\mathrm{mAb}$ recovery observed in $150 \mathrm{mM}$ PBS; $\mathrm{pH}$ 8.0/100 mM citric acid; pH 3.0 buffer system conditions can be attributed to the elution buffer was not able to disrupt completely interactions between the PASFF and mAb. Retention of the CB.Hep-1 $\mathrm{mAb}$ into the matrix was helped by the ligand (Protein $\mathrm{A}$ ) coupled to the matrix and not by unspecific interactions. The buffer system based on $1.5 \mathrm{M}$ glycine- $\mathrm{NaOH} / 3 \mathrm{M} \mathrm{NaCl} ; \mathrm{pH} 9.0 / 200 \mathrm{mM}$ glycine- $\mathrm{HCl}$; $\mathrm{pH} 2.5$ significantly improved the affinity chromatography recovery without affecting the CB.Hep-1 mAb purity, molecular homogeneity, Protein A leakage and mouse DNA content in 100 purification cycles. Application of $1.5 \mathrm{M}$ glycine- $\mathrm{NaOH} / 3 \mathrm{M} \mathrm{NaCl} ; \mathrm{pH} 9.0 / 200 \mathrm{mM}$ glycine- $\mathrm{HCl}$; $\mathrm{pH} 2.5$ as buffer system allowing to reduce the CB.Hep-1 mAb and vaccine cost. As general recommendation, it is necessary to remark that special cares should be taken during preparation and storage of glycine buffers 
Citation: Ferro W, Valdés R, Fernández E, Guevara Y, Medina Y, et al. (2011) Significant Improvements in the Performance of an Established Affinity Chromatography Procedure Employed to Purify a Monoclonal Antibody in 100 Purification Cycles. Pharm Anal Acta 2:143. doi:10.4172/21532435.1000143
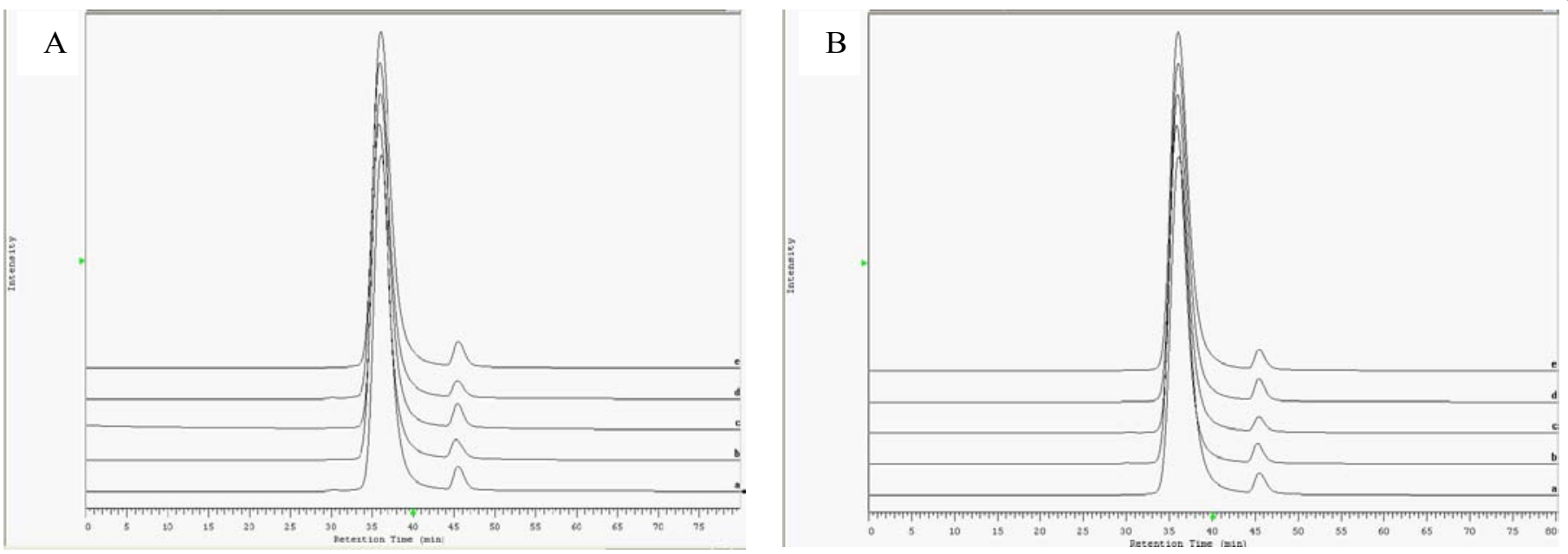

Figure 5: Results of the HPLC-GF analysis to measure the purity of the CB.Hep-1 mAb purified by the PASFF affinity chromatography in the life time study (purification cycles: $91,10,30,60$ and 100). (Left) $150 \mathrm{mM} \mathrm{PBS}$; pH 8.0/100 mM citric acid; pH 3.0 buffer system. (Right) 1.5M glycine-NaOH/3M NaCl; pH 9.0/200 mM glycine-HCl; $\mathrm{pH} 2.5$ buffer system.

for large scale processing because they obviously are more susceptible to microbial contamination.

\section{Acknowledgments}

Authors would like to thank Monoclonal Antibody Department at the Center for Genetic Engineering and Biotechnology and particularly to Dr. Relma Tavares de Oliveira for their respective contributions to this study. This study was totally supported by the Center for Genetic Engineering and Biotechnology.

\section{References}

1. Farid SS (2007) Process economics of industrial monoclonal antibody manufacture. J Chromatogr B 848: 8-18

2. Wilchek M, Miron T (1999) Thirty years of affinity chromatography. React Funct Polym 41: 263-268

3. Swinnen K, Krul A, van Goidsenhoven I, van Tichelt N, Roosen A, et al. (2007) Performance comparison of protein $A$ affinity resins for the purification of monoclonal antibodies. J Chromatogr B 848: 97-107.

4. Hacker D, de Jesús $M$, Wurm $F$ (2009) 25 years of recombinant proteins from reactor-grown cells: where do we go from here? Biotechnol Adv 27: 1023-1027.

5. Low D, O'Leary R, Pujar N (2007) Future of antibody purification J Chromatogr B 848: 48-63.

6. Shukla A, Hubbard B, Tressel T, Guhan S, Low D (2007) Downstream processing of monoclonal antibodies-Application of platform approaches. J Chromatogr B 848: 28-39.

7. Firer MA (2001) Efficient elution of functional proteins in affinity chromatography. J Biochem Biophys Methods 49: 433-442.

8. Hardy E, Martínez E, Diago D, Díaz R, González D, et al. (2000) Large scale production of recombinant hepatitis $B$ surface antigen from Pichia pastoris. J Biotechnol 77:157-167.

9. Lowry OH, Rosenbrough NJ, Farr L, Randal R (1951) Protein measurement with the Folin phenol reagent. J Biol Chem 193: 265-75.

10. Leyva A, Franco A, González T, Sánchez JC, López I, et al. (2007). A rapid and sensitive ELISA to quantify an $\mathrm{HBsAg}$ specific monoclonal antibody and a plantderived antibody during their downstream purification process. Biologicals 35 : 19-25.

11. Laemmli UK (1970) Cleavage of structural proteins during the assembly of the head of Bacteriophage T4. Nature 227: 680-685.

12. Sambrook J, Frstsch E, Maniati T (1980) Molecular cloning. A Laboratory Manual, Second edition (ed), Cold Spring Harbor Laboratory, Press USA.
13. Valdés R, García J, Reyes B, Muñoz, Álvarez T, et al. (2003) A very sensitive enzyme-linked immunoabsorbent assay to Staphylococcal protein $A$ in the presence of immunoglobulins. Biochem Biophys Res Commun 303: 863-867.

14. Gagnon P, (1996) Purification Tools for Monoclonal Antibodies. First published by Validation. Biosystems, Inc, 5800, Tuscon, USA, AZ 85750: 155-203.

15. Bloom J, Wong F, Mitra G (1989) Detection and reduction of Protein A contamination in immobilized Protein A purified monoclonal antibody preparations. J Immunol Methods 117: 83-89.

16. Lucas C, Nelson C, Peterson M, Frie S, Vetterlein D, et al. (1988) Enzymelinked immunosorbent assays (ELISAs) for the determination of contaminants resulting from the immunoaffinity purification of recombinant proteins. J Immunol Methods 113: 113-122.

17. Hahn R, Scimahara K, Steindl F, Junbauer A (2006) Comparison of Protein A affinity sorbents III: Life time study. J Chromatogr A 1102: 224-231.

18. Kurz M (2007) Regulatory considerations regarding quality aspects of monoclonal antibodies. BioPharm Intern 20: 44-52. 